\title{
PER
}

\section{SOFTWARE FACILITATING A COMPARATIVE ANALYSIS OF CASES IN EDUCATION SCIENCES}

\author{
Kálmán Sántha - Balázs Nádler
}

\begin{abstract}
This paper presents a software innovation for research in education science based on the methodological principles of Qualitative Comparative Analysis (QCA). It stresses that the research structure offered by QCA enables selection-free optimization, which can offer new perspectives for education sciences in interpreting pedagogical reality. This process can be facilitated by PED-QCA, which, on the basis of crisp-set QCA principles, opens up a way of using a more adequate fuzzy-set QCA methodology in education sciences. The paper also deals with problems of the software development and algorithm design processes, then illustrates the use of the program in an education science study about pedagogical architecture.
\end{abstract}

Keywords: education science, PED-QCA, Qualitative Comparative Analysis, teacher training.

\section{Introduction}

When studying the development process of a teacher's work, we must give special attention to the steps of becoming a researcher teacher. We have started to introduce this approach in Hungarian teacher training, as the foundations of becoming a researcher teacher must be laid as early as during the years of teacher training, as teacher trainees take part in obligatory research methodology courses, where they can get information about designing and doing pedagogical research. Professionals mainly agree that there is a need for pedagogical research methodology in teacher training and further training, as it can contribute to the efficiency of pedagogical work.

The aim of this paper is illustrating a software developed during a research methodology seminar at the teacher training faculty of the University of Pannonia (Hungary). The paper also answers the question how a course in pedagogical research methodology in teacher training can contribute to enhancing the possibilities of investigating phenomena in education sciences. The program called PED-QCA is based on the algorithms of the crisp-set version of Qualitative Comparative Analysis (csQCA), not so frequently used in Hungarian education sciences. The program performs its basic functions now, in late 2018 , and is to be tested and developed, as our further aim is to cover the full range of QCA typologies. Besides the software functions developed so far, the paper also summarises the uses of QCA so far in Hungarian education sciences. The paper does not detail QCA, it just presents the general elements that are necessary for understanding the operation of the software.

\section{About Qualitative Comparative Analysis (QCA) in brief}

In an Aristotelian sense, science presupposes duality: something must be right or wrong, black or white. This way of thinking simplifies the interpretation of social or pedagogical phenomena, thus leading to loss of information. The abstract interpretation of white or black enables us to analyse uncertain values of linguistic variables, or a logical study of non-linear systems that cannot be analysed using the exact methods of mathematics (Vassinen, 2012). Schneider \& Wagemann (2007) emphasise that most theories 
in social sciences are of linguistic nature, and verbal utterances can be best described using sets instead of using continuously changeable variables.

The scientific community labelled qualitative studies as a process based on inductive logic, recognising that during qualitative induction we infer one quality of a sample based on another quality. Those preferring inductive logic say that science focuses on observable and measurable phenomena, and justifies theories using experiments. Induction was criticised for a long time, which was evidenced in the argument between (the lack of) hypotheses, and objective observation.

Qualitative Comparative Analysis was first described by American sociologist Charles Ragin, who created an algorithm to analyse cases with low case count. In his famous book in 1987 he described the principles of the methodology of comparative analysis (Ragin, 1987). Ragin adopted methodological processes used in engineering (e.g. the Quine-McCluskey algorithm) in social sciences using them in a way that he paid attention to the multivariable nature of human reality, and he offered a solution for standardising inductive processes. In education sciences, it is by all means true that phenomena affecting everyday life are often unique and unrepeatable, and extremely complex. QCA is capable of analysing such complex cases, because it can bridge the "methodological gap" between qualitative studies with a low number of cases and quantitative studies (Ragin, 1987).

Extending one-case studies in order to analyse similar cases comparatively is known as multiple case study. While case studies focusing on one case are capable of discovering deep layers of individual situations, they do not enable comparison from multiple angles because of its context-dependence, multiple case studies enable us to extend the meanings of multiple cases. Multiple case studies use systematic combination, which enables a constant movement between empirical data and generated models (Vassinen, 2012). All this can be interpreted as a research approach in QCA, which focuses on understanding the unique contexts of cases using interpretation in constant movement.

QCA is used in several fields, among others, experts have found its use relevant in information technology, economics, medical science, political science, sociology, law, and international relationships (Schneider \&Wagemann, 2007; Wendler et al., 2013). Discourse in education sciences has also recognised the possibilities offered by QCA, with a special focus on using the methodology of fuzzy-set QCA (fsQCA) in pedagogical research. Feng (1990) demonstrates the use of fuzzy systems in his research about quality in higher education, while Biswas' (1995) study focuses on students' assessment. Sántha (2105) analyses pedagogical spaces, Galántai (2016) studies activities of special interest study groups, both using a crisp-set QCA (csQCA) methodology.

The present version of the PED-QCA software to be presented in this paper is predominantly based on a crisp-set QCA (csQCA) algorithm. The original version csQCA, only works with dichotomised variables: all possible configurations are described as value 0 (false, not fulfilled), or 1 (true, fulfilled). It examines all logically possible combinations to be able to best describe the case (Schneider \& Wagemann, 2007). csQCA changes research methodology terminology as it does not use the concepts dependent and independent variable; instead, it uses outcome for the first and condition for the second. csQCA focuses on defining the necessary and sufficient conditions, the hypothetical truth table, minimisation (Quine-McCluskey algorithm), and interpreting the results. All this is taken into account in the PED-QCA software.

As social phenomena cannot be treated as either true or false, the csQCA method has been criticised for dichotomising, as it reduces the complexity of reality because of loss of information. Besides the dichotomising system of csQCA, it is worth considering a system that can analyse multiple values. Doing so, multi-value QCA (mvQCA) and fuzzy-set QCA (fsQCA) become relevant. Multi-value QCA (mvQCA) is a bridge between csQCA and fuzzy-set QCA (fsQCA), and can use three, four, or even five whole values. In fuzzy-set QCA (fsQCA), multiple values are represented by the use of decimals. 


\section{Methodology QCA in analysing pedagogical phenomena}

Looking at pedagogy as a subsystem of society, we can see that society and pedagogy are in close connection with each other, not just as a whole-part relationship, but they also have structural similarities. To make the connection, we must introduce the notions of 'world' and 'reality'. The world consist of elements in various relations to each other, while reality is constant and exerts an influence (Zsolnai, 1996). Knowing a piece of reality is possible through the world, or one of its pieces. The two notions can be regarded as theoretical and practical levels: still, a condition of practice is existence, a fundamental social motive and reality constructing force that materialises through the system of causes and effects. We emphasise the relationship between pedagogy and society because Ragin developed QCA to study social phenomena. It is therefore worth creating a theoretical background and context that enables us to adapt a QCA methodology in the arsenal of pedagogical research methodology (Sántha \& Nádler, 2018).

To establish QCA as an organic part of studies in education sciences, we must dissolve the contradiction between the key factor of the method, and the nature of pedagogical reality. The dichotomised system of csQCA is opposed to the colourful variety of pedagogical reality. The world of pedagogy cannot be described as black and white, QCA helps us to make comparative analyses based on multiple viewpoints and cases. It is important to note, however, that the focus is not on quantification or simplification, there is no break with complex reality, but there is a comparative analysis of the elements of pedagogical reality that either interact with each other, or do not. To be able to analyse a segment of pedagogical reality, we must create models. Behind 0 and 1 we find concepts to be interpreted, so the quantitative part of QCA is responsible for selection, and the qualitative segment is used to create combinations. As we can see, csQCA yields comprehensible and transparent results, but also generates data loss. On the other hand, fsQCA makes a more complex analysis based on the intermediary categories between 0 and 1 , introducing words like "almost, hardly, mostly", which only get their full meaning in relation to the variables.

The first task of QCA is optimising. In education sciences this can have negative consequences, as all optimisation is also selection. Education science in the $21^{\text {st }}$ century tries to exclude this option. The analysis structure offered by QCA offers a possibility for optimisation without selection, as, for example, all students are capable of happy and efficient learning, albeit in ways that might not have been discovered so far. Using selection based on students' learning habits and integrating the factors of efficient learning, QCA can provide information for the teaching and learning process, so it can also influence its efficiency (Sántha \& Nádler, 2018).

In research in education sciences, the goal is a study of phenomena, situations, and individuals influenced by several factors. The study keeps in mind that these are individual cases, where it is important to explain the outcomes and reasons of the cases in detail. We might ask the question 'what does the efficiency of learning depend on?' Taking the features of QCA into consideration, the question can be modified as follows: 'what does the efficiency of learning depend on in case X or Y?' This way we can see the concrete cases, the reasons behind them, and also the outcomes.

\section{Software in the QCA discourse}

Analyses based on the QCA methodology are supported by several programs, you can get information about them on the www.compasss.org webpage. Depending on QCA typologies, we can use efficiently the fsQCA (Ragin \& Davey, 2012), the Kirq (Reichert \& Rubinson, 2013), the R Package QCA (Thiem \& Duşa, 2013), or the Tosmana (Cronqvist, 2011) programs.

The software development in QCA described here can be seen as a first in Hungarian education sciences. We started to develop a program for crisp-set QCA (csQCA) at the teacher training faculty of the University of Pannonia, during a pedagogical research methodology seminar led be the author of the present paper in the year 2015/2016. The students were free to opt for research tasks concerning school 
life, pedagogy, the theory and practice of education according to their personal tastes. Balázs Nádler, one of the students, now a teacher himself, ventured to write a program. After months of work, the program was finished. It bears the name PED-QCA to indicate the usability of its methodological background in education sciences. Its primary aim is to create the algorithm on the basis of the data entered without manual calculation, and to make an output for the researcher that can be used directly in pedagogical research.

When designing PED-QCA we had to consider several factors (Sántha \& Nádler, 2018): we had to design a user-friendly interface, which follows not just the programmer's logic but also the way of thinking of experts working in the field of education. The main moment of writing the program was designing the algorithm process. We chose csQCA based on a Boolean algebra as minimising the values 0 and 1 provides for easier and more prototypical execution than working with a fuzzy type. During testing, the program was optimised for a number of variables between 3 and 5, which was supposed to be enough for describing pedagogical phenomena.

The first step of creation was choosing the programming language (Object Pascal). This decision was supported by the fact that this language has strong typing, that means all the variables used in the program must be declared. The language thus distinguishes between whole numbers (integers), and decimals (float, double). The second question was compatibility between operating systems. Our choice fell upon Java as it has much greater support than the original Object Pascal language. The third step is extending the program, this consists of three elements. The first and most important is adding a fuzzy function, which is much more useful in research in education sciences than the crisp function. One convenience option is language selection, which makes the program internationally available. There is also a report making module, which is handled by the program using minimised results and given data. To this, we can add all modules supported by Java (e.g. Dynamic Reports, iReport). The document made this way can transparently represent the whole minimisation process.

The whole program is now under construction until it reaches a stage when it can be used as a tool in a theoretical pedagogical system.

\section{PED-QCA in an empirical study in education sciences}

This paper presents the use of PED-QCA on the basis of an example is education sciences, using a paper by Sántha (2015) on pedagogical architecture. During the study, correspondence students wrote down their thoughts about classroom spatial structure in an unstructured reflective diary. In their imagination, they formed space to make it the most efficient for the teaching and learning process. Data analysis was done using csQCA (crisp-set QCA).

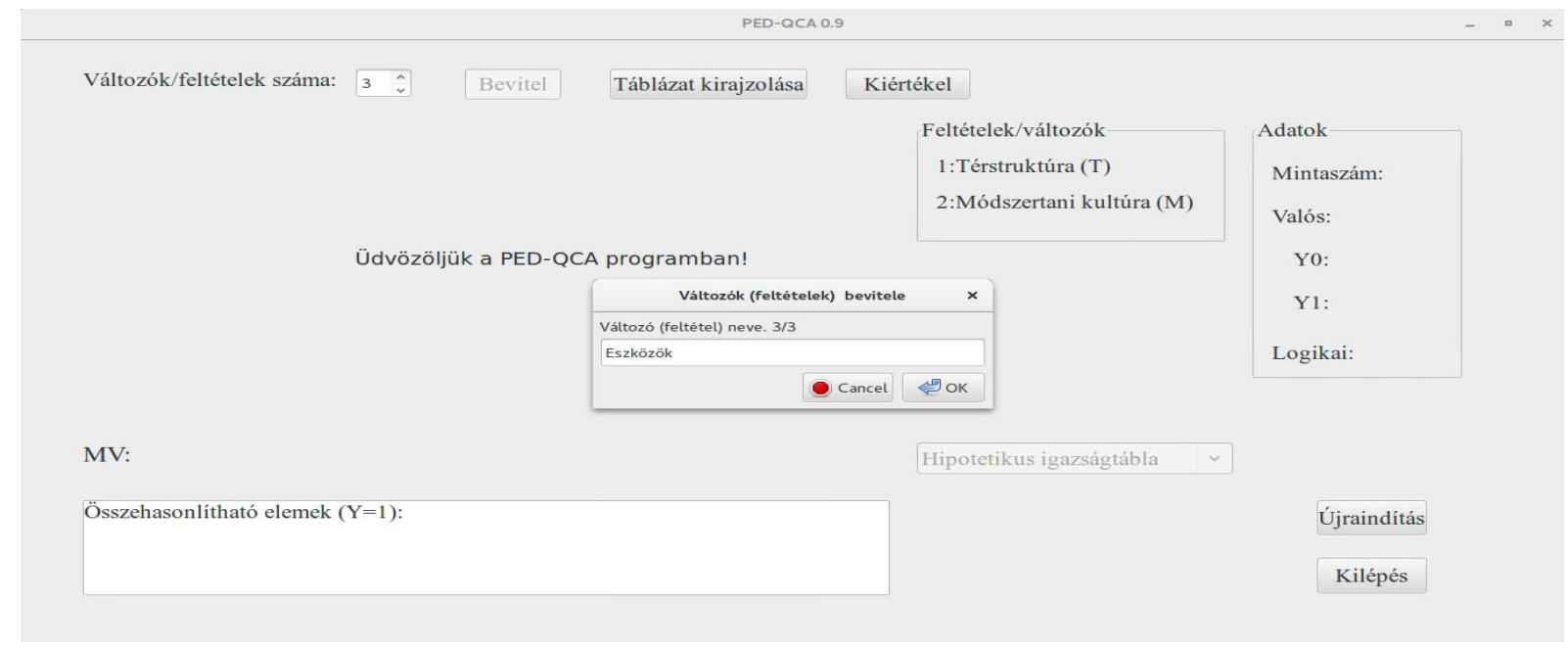

Fig.1. Entering conditions (Sántha \& Nádler, 2018, p. 83.) 
The first step was creating the conditions by means of analysing the reflective diary using inductive content analysis. The conditions (spatial structure $-\mathrm{T}$, methodological culture $-\mathrm{M}$, educational tool E) were defined by main categories extracted from the texts. As a first step, the program asks for the number of conditions, so it creates as many entry options as many conditions there are (Figure 1).

Since PED-QCA software is developed in Hungarian, the subtitles of the screenshots are also in Hungarian. The translations of the subtitles are the following: változók/feltételek száma - number of conditions; táblázat kirajzolása - display chart; kiértékel - evaluate; feltételek/változók conditions/variables; Térstruktúra $(\mathrm{T})$ - spatial structure; Módszertani kultúra - methodological culture; Adatok - Data; Mintaszám - Sample; Valós - Real; Logikai - Logical; Üdvözöljük a PED-QCA programban - Welcome to PED-QCA; Változók (feltételek) bevitele - Insert conditions; Összehasonlítható elemek - Comparative elements; Újraindítás - Reset; Kilépés - Logout.

The second step is creating the hypothetical truth table on the basis of the conditions. The columns in Figure 2. show conditions and outputs, lines represent cases. In the cells, 1 and 0 indicate whether the given condition is fulfilled or not. As in csQCA all conditions have two outcomes (either 0 or 1), the independent condition $\mathrm{n}$ will have $2^{\mathrm{n}}$ different configurations. So based on the three conditions from the inductive content analysis of reflective diaries, the truth table will consist of eight different configurations.

\begin{tabular}{|l|l|l|l|l|l|l|}
\hline No. & T & M & E & Kimenet $(\mathrm{Y})$ & Mintaszám $(\mathrm{N})$ & Megjegyzés \\
\hline 1 & 0 & 0 & 0 & 0 & 3 & \\
\hline 2 & 1 & 0 & 0 & 1 & 7 & 0 \\
\hline 3 & 0 & 1 & 0 & $?$ & 7 & \\
\hline 4 & 1 & 1 & 0 & 1 & 1 & \\
\hline 5 & 0 & 0 & 1 & 1 & 4 & \\
\hline 6 & 1 & 0 & 1 & 1 & 0 & \\
\hline 7 & 0 & 1 & 1 & $?$ & 7 & \\
\hline 8 & 1 & 1 & 1 & 1 & & \\
\hline
\end{tabular}

Fig. 2. Hypothetical truth table in PED-QCA (Sántha \& Nádler, 2018, p. 83.)

Key to Figure 2.: Kimenet (Y) - Output; Mintaszám - Sample; Megjegyzés - Notes

The hypothetical truth table gives us the number of all the possible variations, some of which might not actually appear in reality. Thus, besides real cases ( $\mathrm{Y}=0 \mathrm{v} 1)$, we also found logical cases (lines 3 and 7 , where $\mathbf{N}=0$ ), which are true configurations only mathematically, i.e. they are not based on cases actually observed.

The third step is comparing the cases in the truth table. First, we examined cases which yielded the same outcome in the case of all independent conditions. At this stage it was important to define the processes of addition and multiplication. Boolean sums represented logical "or", while multiplication meant a combination of conditions, so it was interpreted as "and". All cases can be described as Boolean multiplications, where capital letters mean fulfilled conditions (1), and small letters mean unfulfilled conditions (0). $\mathrm{Y}=1$ is fulfilled by cases $2,4,5,6$, and 8 , that is $\mathrm{Y}(1)=\mathrm{TME}+\mathrm{TMe}+\mathrm{Tme}+\mathrm{TmE}+$ tmE. This expression is the primitive expression for $Y=1$. $Y=0$ is fulfilled by case 1 , where $m v=$ tme. This latter is the primitive expression for outcome $\mathrm{Y}=0$.

After defining primitive expressions, a logical minimisation of configurations was done. This process can only be interpreted in real cases. The essence of Boolean minimisation is looking for configurations that explain one or more cases using a certain outcome. During minimisation, the Quine-McCluskey 
algorithm can be used. As only configurations with the same outcome can be compared, the comparison of outcomes 0 and 1 can only be made in different paths. Minimising is a two-step process in the case of the primitive expression $\mathrm{Y}=1$, the first is looking for and comparing neighbouring combinations pair by pair, the second is creating the primeimplicant table. During minimisation, the following expression results, and this cannot de reduced any more: $\mathrm{Y}(1)=\mathrm{T}+\mathrm{mE}$, the interpretation of which is the following: an efficient teaching and learning process results $(\mathrm{Y}=1)$ if adequate spatial structure $(\mathrm{T})$ or non-adequate methodological culture $(\mathrm{m})$ and a varied use of tools $(\mathrm{E})$ is present in the classroom.

By using the "Evaluation" function we can access the data of comparable elements, and we can also get the fulfilment conditions, and the table containing the primitive expressions and the primeimplicant table. A further step of this analysis is generating theories, which starts from the minimised expression and can be done using the principles of qualitative analysis.

\section{Conclusion}

QCA deals with the comparison of cases, it analyses possible combinations of conditions and outcomes, creating its own terminology and system of algorithms. PED-QCA aimed at contributing to this process. This initiative is a new proof of the hope that complex research methodology can get a relevant place in research about education sciences. It also indicates that Hungarian education science is open to complex developments in research methodology. PED-QCA has the aim of serving as a tool to improve educational practices. The software can be used when doing research on pedagogy in teacher training, in scientific student research, Ph.D. dissertations, as well as in teachers' further training. The aim is developing a software that satisfies the demands of scientific researchers in education sciences.

During the analysis steps of this study, reflection was always present. It catered for the diagnosis and development of research activity, it prevented making premature decisions, and contributed to the logical construction and consistent presentation of the research process and the results. Analysts consciously took this into account and relied on collegial reflection.

\section{Bibliography}

Biswas, R. (1995): An Application of Fuzzy Sets in Student's Evaluation. Fuzzy Sets and Systems, 74. 187-194.

Cronqvist, L. (2011): Tosmana: Tool for Small-N Analysis. University of Trier, Trier.

Feng, C. (1990): Quantitative Evaluation of University Teaching Quality - An Application of Fuzzy Sets and Approximate Reasoning. Fuzzy Sets and System, 37. 1-11.

Galántai, L. (2016): Rendszerszerủ pályák. A sikeres egyetemi felvételi szocializációs előzményei a PTE Wlislocki Henrik Szakkollégiumában (Systemic Career Path. The Antecedent of Socialization of Successful University Admission at the PTE Wlislocki Henry College). Educatio, 3. 348-358.

Ragin, C. (1987): The Comparative Method. Moving Beyond Qualitative and Quantitative Strategies. University of California Press, Berkeley/Los Angeles/ London.

Ragin, C. \& Davey, C. (2012): fs/QCA (Computer Programme). University of California, Irvine.

Reichert, C. \& Rubinson, C. (2013): Kirq. (Computer Programme). University of Houston-Downtown, Houston.

Sager, F. \& Ledermann, S. (2013): Qualitative Comparative Analysis (QCA) und realistische Evaluation. Theoretische Parallelen und eine praktische Anwendung. http://nbnresolving.de/urn:nbn:de:0168-ssoar-144025 (20.11.2013). 
Sántha, K. (2015): Kvalitatív Komparatív Analízis a pedagógiai térábrázolásban (Qualitative Comparative Analysis in the Analysis of Pedagogical Spaces). Iskolakultúra, 3. 3-14.

Sántha, K. \& Nádler, B. (2018): PED-QCA innováció a hazai neveléstudományi vizsgálatok számára (PED-QCA Innovation for Educational Research in Hungary). Neveléstudomány. Oktatás-KutatásInnováció, $1.78-86$.

Schneider, C. O. \& Wagemann, C. (2007): Qualitative Comparative Analysis (QCA) und Fuzzy Sets. Verlag Barbara Budrich, Opladen.

Thiem, A. \& Duşa, A. (2013): QCA: A Package for Qualitative Comparative Analysis. The R Journal, 5 (1). 87-97. http://journal.r-project.org/archive/2013-1/thiem-dusa.pdf.(26.01.2014).

Vassinen, A. (2012): Configurational Explanation of Marketing Outcomes. A Fuzzy-Set Qualitative Comparative Analysis Approach. Aalto University Finland, Helsinki. www.stratmark.fi/wpcontent/uploads/Antti\%20Vassinen CEMO.pdf.(05.05.2014).

Wendler, R., Bukvova, H. \& Leupold, S. (2013): Qualitative Comparative Analysis in Information Systems and Wirtschaftsinformatik. www.wi2013.de/proceedings/wi2013\%20-\%20Track10Wendler.pdf.(11.12.2013).

Zsolnai, J. (1996): Bevezetés a pedagógiai gondolkodásba (Introduction to the Pedagogical Thinking). Nemzeti Tankönyvkiadó, Budapest.

\section{Authors}

Kálmán Sántha, associate professor, Kodolányi János University, Orosháza/Székesfehérvár/Budapest (Hungary). E-mail: skalman@kodolanyi.hu.

Balázs Nádler, Teacher of Hungarian Grammar and Literature, Veszprémi Szakképzési Centrum Ipari Szakgimnáziuma, Veszprém (Hungary). E-mail: balazsnad@gmail.com. 
